\title{
A VERIFICATION ANALYSIS FOR PILES IN LIQUEFIABLE SOIL
}

\section{Pınar Sezin ÖZTÜRK KARDOĞAN*, Nihat Sinan IŞIK}

Gazi Üniversitesi, Teknoloji Fakültesi, İnşaat Mühendisliği Bölümü, Ankara, Türkiye

\begin{tabular}{ll}
\hline Keywords & Abstract \\
Liquefiable Soil, & The soil loses its strength and behaves like a liquid when increasing the pore water \\
File Foundation, & $\begin{array}{l}\text { pressure under dynamic loads in saturated sandy soils. The large soil displacements } \\
\text { can occur on liquefied soil. Pile foundations are applied to bearing capacity } \\
\text { problems soil which may be subjected to large lateral displacements due to } \\
\text { Finite Difference Method. } \\
\text { liquefaction. Although there are many theoretical and practical studies on the } \\
\text { behavior of laterally loaded piles in liquefiable soils, there is still no definitive } \\
\text { method. The pile damages which are occurred by lateral spreading resulting from } \\
\text { liquefaction under dynamic loads have been investigated by many scientists and } \\
\text { studies on the causes of damages have increased. Pile response in liquefiable soils } \\
\text { and the evaluation of its possible damage are generally assessed by using some } \\
\text { available numerical method, for example, the finite difference (FDM), finite element } \\
\text { (FEM), and boundary element (BEM) methods. In this paper, the FDM method is } \\
\text { used to study the pile behavior in liquefiable soils and its reliability is checked by } \\
\text { comparison with centrifuge test results from the literature. It, in which the effect of } \\
\text { liquefaction-induced lateral spreading on the pile was evaluated, are also studied. } \\
\text { Finally, the analysis results with FLAC 2D are compared with those observed in a } \\
\text { centrifuge experiment. }\end{array}$ \\
\hline
\end{tabular}

SIVILAŞABİLİR ZEMİNLERDE KAZIK DAVRANIŞINA AİT DOĞRULAMA ANALİZí

\begin{tabular}{|c|c|}
\hline Anahtar Kelimeler & Öz \\
\hline $\begin{array}{l}\text { Sivilaşan Zemin, } \\
\text { Kazık Temel, } \\
\text { FLAC 2D, } \\
\text { Sonlu Farklar Metodu. }\end{array}$ & $\begin{array}{l}\text { Suya doygun kumlu zeminlerde dinamik yükler altında boşluk suyu basıncının } \\
\text { artması sonucunda zemin mukavemetini kaybeder ve sıvı gibi davranır. Bunun } \\
\text { sonucunda sıvılaşan zeminlerde büyük zemin yerdeğiştirmeleri meydana gelebilir. } \\
\text { Taşıma gücü problemleri olan zeminler için kullanılan kazık temeller sıvılaşma } \\
\text { olayından dolayı büyük yanal yerdeğiştirmelere maruz kalabilirler. Yatay yüklü } \\
\text { kazıkların dinamik yükler altındaki davranışını üzerinde yapılmış birçok nümerik } \\
\text { ve deneysel çalışmalar olmasına rağmen, sıvılaşan zeminlerdeki kazık } \\
\text { davranışlarını kesin yargılarla belirlemek çok mümkün değildir. Dinamik yükler } \\
\text { altında meydana gelen sıvılaşma ve sıvılaşma sonucunda oluşan yanal yayılmanın } \\
\text { kazıklarda meydana getirdiği hasarlar birçok bilim adamı tarafından araştırımışve } \\
\text { oluşan hasarların sebepleri üzerinde yapılan çalışmalar artmıştır. Sıvılaşan } \\
\text { zeminlerde kazık davranışı belirlemek için kullanılan bazı sayısal yöntemler } \\
\text { mevcuttur, örneğin; sonlu farklar metodu (FDM), sonlu elemanlar metodu (FEM), } \\
\text { sınır eleman metodu (BEM). Bu çalışmada, sıvılaşan zemindeki yanal yüklü kazık } \\
\text { davranışının analiz sonuçları ile literatürden alınan santrifüj deney sonuçları } \\
\text { karşlaştırılmıştır. Sayısal analizler FLAC2D sonlu farklar programı kullanılarak } \\
\text { yapılmıș elde edilen sonuçlar santrifüj deney sonucu ile kontrol edilmiștir. }\end{array}$ \\
\hline
\end{tabular}

Alıntı / Cite

Öztürk Kardoğan, P.S., Ișık, N.S., (2020). A Verification Analysis for Piles in Liquefiable Soil, Journal of Engineering Sciences and Design, 8(3), 712-719.

\footnotetext{
* ilgili yazar / Corresponding author: sezinozturk@gazi.edu.tr, +90- 0-312-2028897
} 


\begin{tabular}{l|l|l}
\hline Yazar Kimliği / Author ID (ORCID Number) & \multicolumn{3}{|l}{ Makale Süreci / Article Process } \\
\hline P.S. Öztürk Kardoğan, 0000-0002-5212-4318, & Başvuru Tarihi / Submission Date & 10.04 .2020 \\
N.S. Işlk, 0000-0002-5104-9504 & Revizyon Tarihi / Revision Date & 24.08 .2020 \\
& Kabul Tarihi / Accepted Date & 01.09 .2020 \\
& Yayım Tarihi / Published Date & 24.09 .2020 \\
\hline
\end{tabular}

\section{Introduction}

Soil liquefaction is a phenomenon that can lead to severe structural damages and geotechnical problems. Earthquakes, which occur frequently in Turkey and all over the world, have caused the occurrence of liquefaction several times in the past, thus leading scientists and engineers to find proper solutions able to mitigate the effects of such phenomenon in urban and industrial areas.

Recent and past studies have suggested that liquefaction may occur on saturated cohesionless soils during earthquakes. Liquefaction is a phenomenon that occurs in saturated cohesionless soils losing their strength and behaving like a liquid because of the increased pore water pressure.

Pile behavior in liquefiable soils has become a special geotechnical research field in the recent past and it is still an important topic nowadays. Past and present studies have shown pile foundation damages after liquefaction and their consequences on the built environment. Tokimatsu and Asaka (1998) carried out a study about the damages the occurred on piles (especially at the depth in which the interface between liquefiable and nonliquefiable soil layers was located) and about the pile deflection (and failure) modes after the 1995 Hyogoken-Nambu earthquake. Cubrinovski et al. (1999) carried out shaking table tests and analytical studies providing new insights about the cyclic stage of the soil-structure interaction and showing damages that occurred on piles.

Pile design under earthquake loading in liquefiable soils is a very important task that involves several issues to be solved (Finn and Fujita, 2002). As an example, the increased pore-water pressure due to the earthquake shaking should be properly accounted. The latter issue was considered in the work of Liyanapathirana and Poulos (2002) which developed a simplified effective stress-based numerical model to study pile response during soil liquefaction. In the past, some researchers, while studying the behavior of pile foundation in liquefiable or weak soils by using the code FLAC 3D, have ignored inertial loads and vertical loads from the superstructure. Thus, it was assumed that the single pile and the pile group were only subjected to kinematic loading induced by ground movements and by lateral spreading in case of sloping ground (Martin and Chen, 2005). Several works have shown and demonstrated that pile group effects (i.e. shadowing effect, edge effect, and block/row failure), which are relevant in case of static lateral loads after liquefaction lose their importance (Rollins et al., 2005). Thus, it is generally possible to simplify the pile group problem studying the single pile case.

The finite difference code FLAC 3D was used to study the effects of the 1995 Hyogo ken Nambu earthquake on a pile-supported wharf and to perform some parametric analyses (Takahashi and Takemura,2005). In some shaking tables, tests were carried out on a steel-pile and a pre-stressed high-strength concrete pile in liquefiable soil (Cubrinovski et al.,2006). In the latter work, it was found that a relatively flexible pile follows the ground movements while a stiff pile does not follow entirely the soil movements and its response is also affected by the development of higher lateral resistance compared to the flexible pile case. Madabhushi et al. (2010) collected data and reports about damages that occurred on piles. Additionally, the case study of the Landing bridge (which was damaged by lateral spreading) was investigated and the plastic capacities of the bridge's piers and piles were examined in detail (Berril et al.,2001). Bhattacharya et al. (2014) stated that the Showa Bridge, which was damaged during the Niigata earthquake in 1964, suffered from liquefaction damage. Also, Yoshida et al. (2007), also stated that the lateral spreading occurred after the damage of the piers of the Showa bridge, which was damaged in the Niigata earthquake in 1964.

To better reproduce the behavior of pile foundations in liquefiable soils, many researchers have compared the results of centrifuge experiments with numerical analyses. Haldar and Babu (2010) compared the results of FLAC $2 \mathrm{D}$ analyses with those inferred in the centrifuge tests performed by Wilson et al. (2000) and they found that their numerical results were close to those experimentally observed. Heidary-Torkamani et al. (2014) compared the results of their FLAC 2D numerical model with the results of centrifuge tests carried out at the University of California to understand the pile behavior in pile-supported coastal structures. Moreover, centrifuge experiments and numerical studies permitted to show that pile-soil interactions are affected by the earthquake properties (i.e. number of cycles, magnitude, duration, intensity, peak acceleration and predominant period) and soil conditions (Dobry and Liu, 1994; Liyanapathirana and Poulos, 2003; Ishihara and Cubrinovski, 1998; Boulanger et al., 1998). According to other centrifuge results in the literature, after the liquefaction, lateral spreading may occur and may 
affect negatively the single pile and the pile group behavior (Abdoun et al.,2005; Dobry et al., 2003; Brandenberg et al., 2005; Chang et al., 2005).

In this study, the results of a centrifuge test from literature and the analysis results obtained using the finite difference code FLAC 2D have been compared. At the end of the analysis, the reliability of the finite difference code used herein for the analysis of the pile foundation in liquefiable soil is discussed.

\section{Finite Differences Method}

One of the numerical methods used to understand the behavior of pile foundations in liquefied soils is the finite difference method. In the finite difference method, the differential values of the unknown function are converted to differential equations by applying finite differences to the function values (Mazak, 2016). The finite difference method is the process of dividing the function of the problem into equal intervals and obtaining the result with the solution of this function. The division into equal intervals is the discretization process. The discretization procedure in the finite difference method is caused by the change in the variable of the constant derivatives of the equations that govern the physical problems through a small but finite increase (Tyagi, 2015).

The finite difference code FLAC 2D, used in this study, is a program that models the soil liquefaction phenomenon and pile-soil interaction during liquefaction at the same time. Thanks to advanced constitutive models included in this program, realistic soil behavior in liquefaction conditions can be simulated during the analyses.

In this paper; the Finn-Byrne Liquefaction Model developed by Byrne is used to model the liquefiable soil layer behavior and the Mohr-Coulomb constitutive model is used in non-liquefiable soil layers (FLAC2D; Byrne, 1991). By using the Finn-Byrne Liquefaction Model, the build-up (i.e. generation) of excess pore water pressures is obtained by calculating permanent volumetric strains during dynamic analysis. In this model, the void ratio can be calculated as a function of the volumetric strain and other parameters (FLAC2D; Byrne, 1991).

\section{Verification Analysis}

\subsection{Centrifuge Test and Finite Difference Analysis}

In this work, the centrifuge experiments presented by Abdoun and Wang (2003) were numerically analyzed. The model consisted of three soil layers (Figure 1, in prototype scale): a top layer of non-liquefiable slightly cemented sand, an intermediate layer of liquefiable Nevada sand (relative density $=40 \%$ ) and a bottom layer of nonliquefiable slightly cemented sand having a thickness of $2 \mathrm{~m}, 6 \mathrm{~m}$, and $2 \mathrm{~m}$, respectively (in prototype scale). In the centrifuge model, the soil was saturated with viscosity-adjusted fluids (Abdoun and Wang, 2003).

The prototype was inclined to the horizontal surface at an angle of 4.8 degrees. Thus, lateral spreading was ensured during the experiment. At the base of the centrifuge box, variable horizontal accelerations in the form of a sine wave with a maximum value of $0,25 \mathrm{~g}$ at a frequency of $2 \mathrm{~Hz}$ were applied. Figure 1 shows the centrifuge model on the prototype scale.

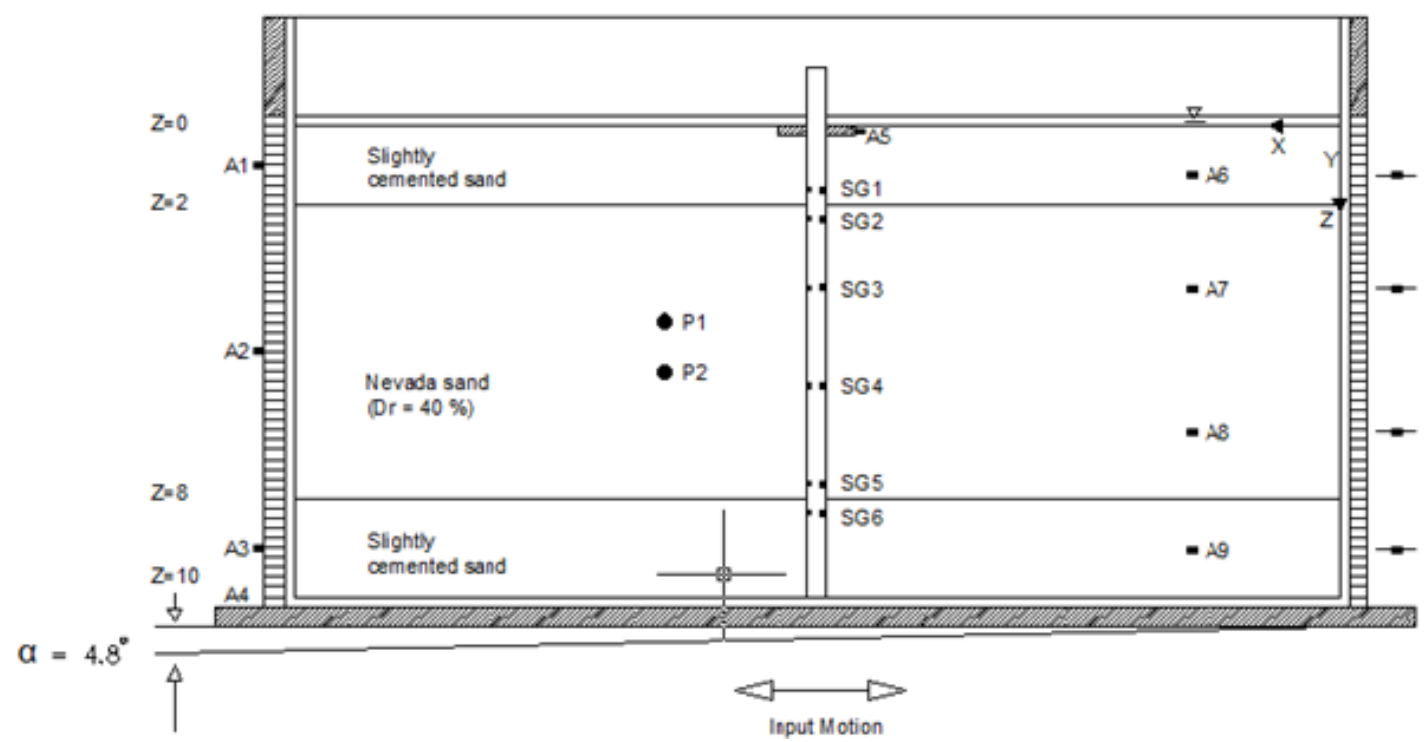

Figure 1. Centrifuge model used for the verification analysis (modified from Abdoun and Wang, 2003) (dimensions in prototype scale) 
The pile diameter (D) and flexural rigidity (EI) were $60 \mathrm{~cm}$ and $8000 \mathrm{kNm}^{2}$, respectively (in prototype scale). Pilehead was fixed against rotation. The box used in the centrifuge experiments was a laminar box. The box, was constructed with flexible elements to simulate free field conditions, allowed permanent horizontal deformations. Therefore, also the boundaries of the FLAC 2D model were modeled as free-field boundaries during the dynamic analysis (FLAC2D- Fast Lagrangian Analysis of Continua User Guide, 2002). Free-field boundaries simulate the presence of infinite soil conditions. Since the model is two dimensional, plane strain conditions are assumed.

Finite difference analysis consists of four stages. In the first stage, the total stresses due to the soil weight were modeled (i.e. the generation of the initial stresses phase was obtained with the gravity loading procedure (FLAC2D; FLAC2D- Fast Lagrangian Analysis of Continua User Guide, 2002). In the second stage, only the water flow solution was created. The model included the water table depth, thus the hydrostatic water pressures were computed. In the third stage, the solution is provided by making a numerical solution. Thus, it is ensured that the model reaches equilibrium before the dynamic analysis. In the final stage, dynamic analyses were performed using the Finn-Byrne Liquefaction Model for the intermediate liquefiable layer. The elements and the boundary conditions used in the 2D finite difference analysis are shown in Figure 2. The horizontal size of the model was chosen as four times the depth so as not to be affected by the right and left free-field boundaries. In Figure 3, the hydrostatic pore water pressures are presented for fully-saturated soil conditions as a result of the static analysis.

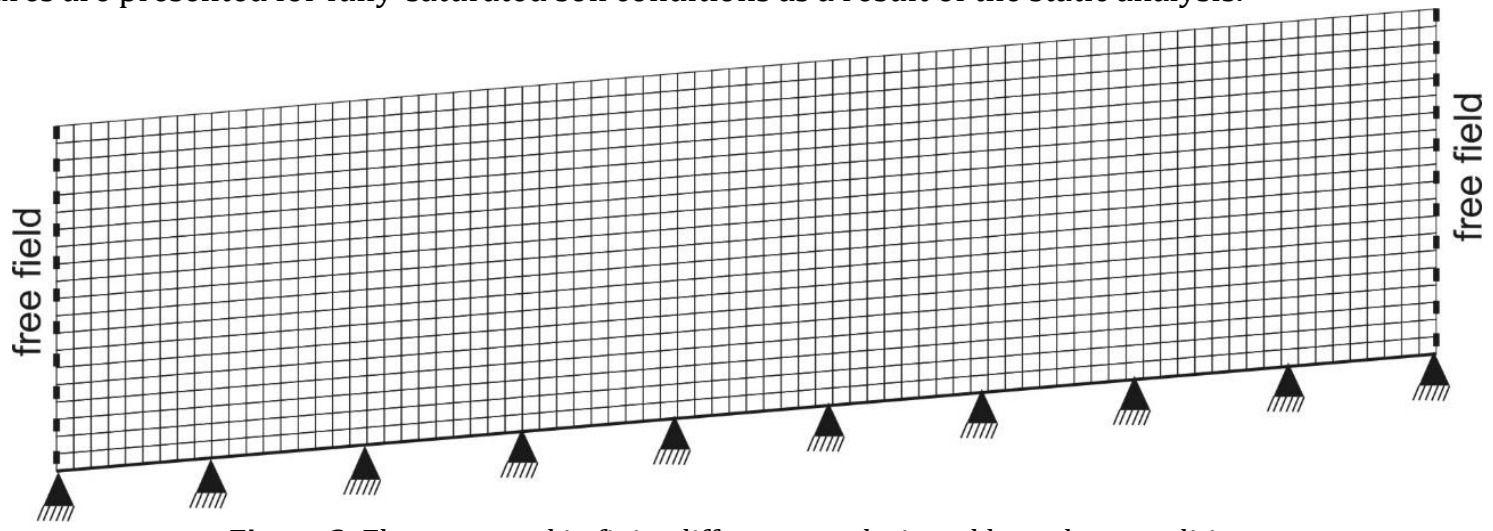

Figure 2. Elements used in finite difference analysis and boundary conditions

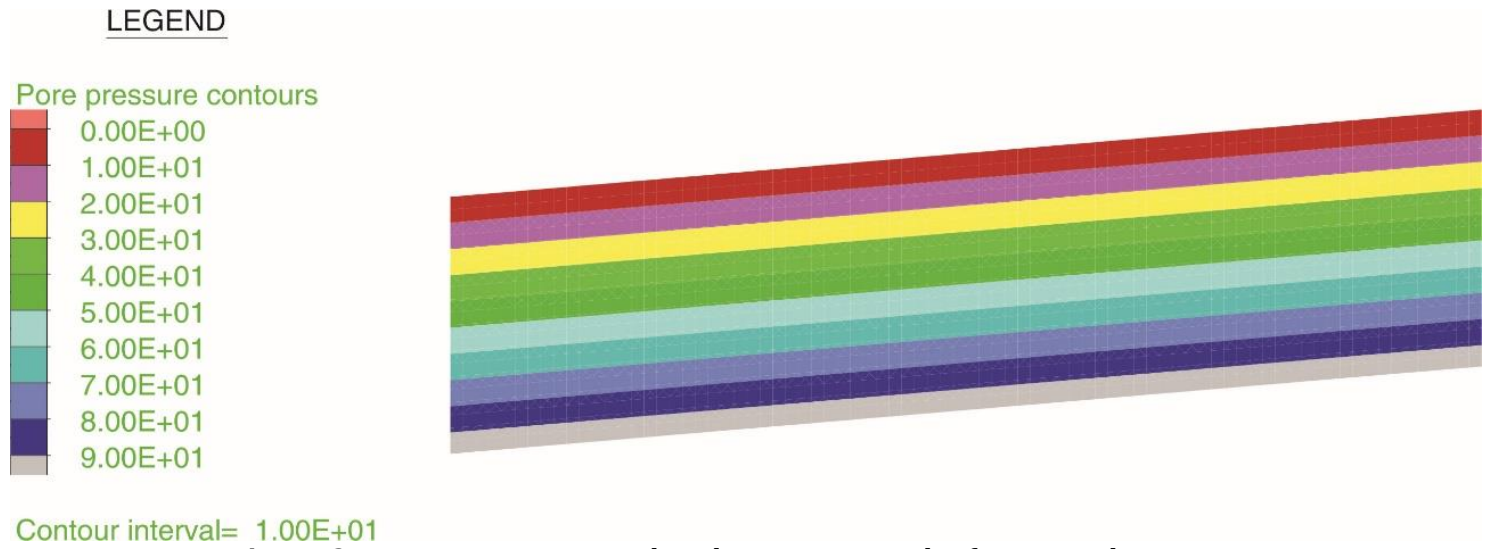

Figure 3. Pore water pressure distribution as a result of static analysis stages

The Finn-Byrne model requires as input the constants $\mathrm{C} 1$ and $\mathrm{C} 2$, which relate the increment of volume decrease $\left(\Delta \varepsilon_{\mathrm{vd}}\right)$ and the increase of pore water pressure with cyclic shear-strain amplitude $(\gamma)$. In this work, the constants $\mathrm{C} 1$ and C2 of the liquefiable Nevada sand (relative density, $\mathrm{Dr}=40 \%$ ) were calculated using the Equations 1 and 2 reported in the FLAC manual (FLAC2D- Fast Lagrangian Analysis of Continua User Guide, 2002) and based on the work of Byrne, 1991. Thus, C1 and C2 were calculated as 0.764 and 0.523 , respectively. The angle of friction of the Nevada sand at a relative density of $40 \%$ was taken as 33 degrees (Arulmoli et al.,1992). Besides, an effective cohesion of $10 \mathrm{kPa}$ was obtained for the slightly cemented sand layers, which were modeled with the MohrCoulomb constitutive model. Shear modulus values of Nevada sand and cemented sand are taken as 10 and 12 $\mathrm{MPa}$. Bulk modulus values are calculated using a Poisson's ratio of 0.3. During the dynamic analysis, Rayleigh-type damping was added to the hysteretic damping of the materials to model the soil viscous damping at small-strain levels, to reduce unrealistic amplifications at high frequencies. The viscous damping ratio was set equal to 2 and $5 \%$.

$$
\mathrm{C} 1=7600(\mathrm{Dr})-2,5
$$




$$
\mathrm{C} 2=0,4 / \mathrm{C} 1
$$

Pile-soil interface parameters that control pile-soil interaction during lateral spreading are taken as reported in FLAC 2D manual (FLAC2D- Fast Lagrangian Analysis of Continua User Guide, 2002) and briefly described in Figure 4. Because the model thickness in the prototype scale is about 10 meters, the pile parameters are scaled for plane deformation analysis.

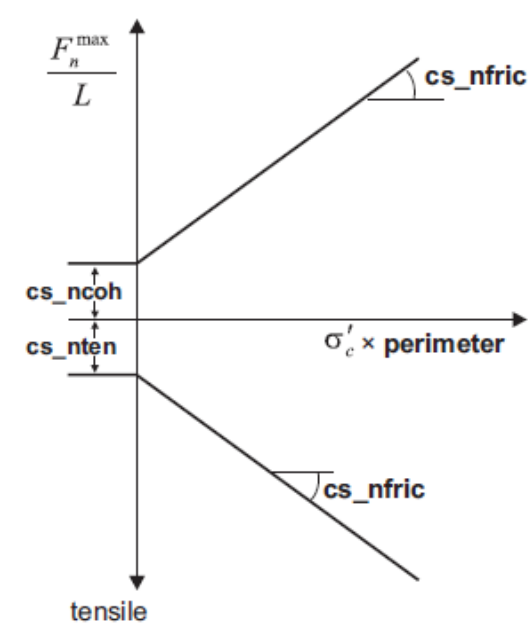

a) Normal strength criterion

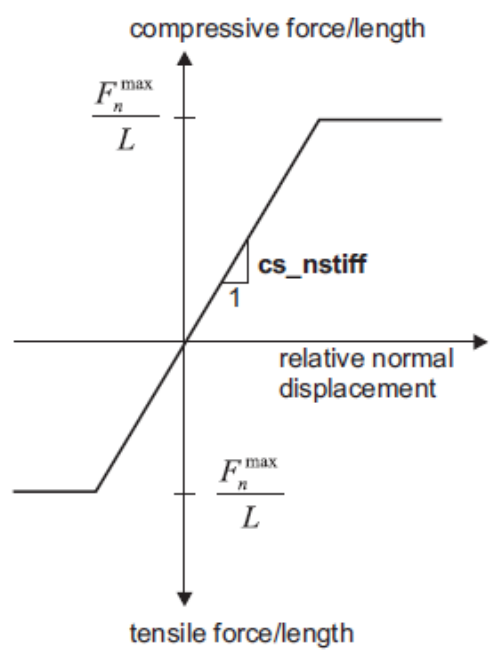

b) Normal force versus displacement

Figure 4. Pile-soil interaction parameters (FLAC2D- Fast Lagrangian Analysis of Continua User Guide, 2002)

Abdoun and Wang (2003) reported that the pore pressure ratio (ru= total pore pressure over total overburden stress) measured in centrifuge experiments after 5 cycles ( 2.5 seconds) attained a value equal to 1 (full liquefaction condition) and that this value kept constant up to the end of the loading. Therefore, in the FLAC analysis, the pore water pressure value in the middle of the intermediate liquefiable Nevada sand layer was monitored. Figure 5 shows the pore water pressure ratio vs. time graph for the analysis where a $5 \%$ viscous damping ratio at small strain level was used. Examining Figure 5, it can be observed that the pore water pressure ratio reaches its maximum value approximately at 2.5 seconds and keeps constant up to the end of the dynamic analysis. Figure 6 shows the pore water pressure distribution obtained at the end of the dynamic loading around the pile.

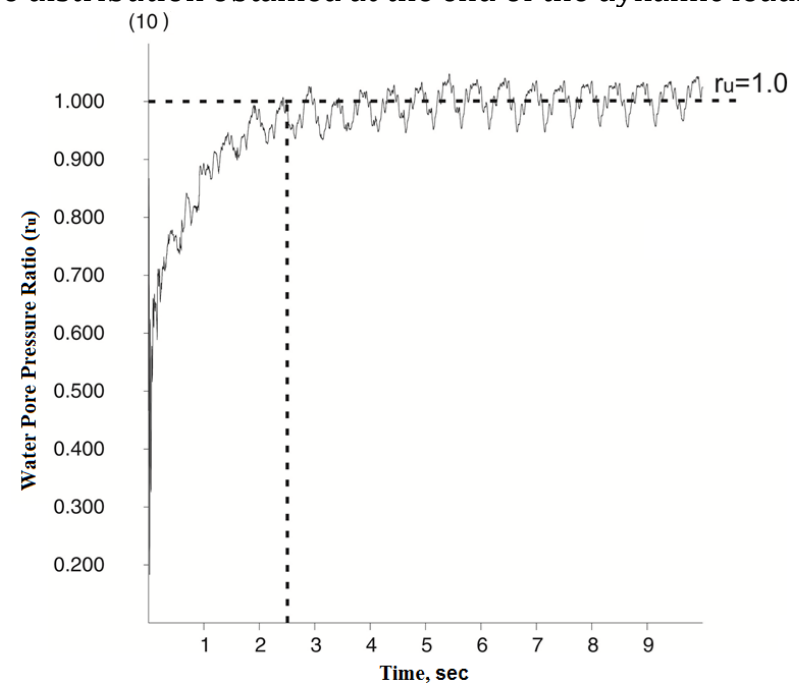

Figure 5. Pore water pressure ratio vs. time graph in the analysis with a $5 \%$ viscous damping 


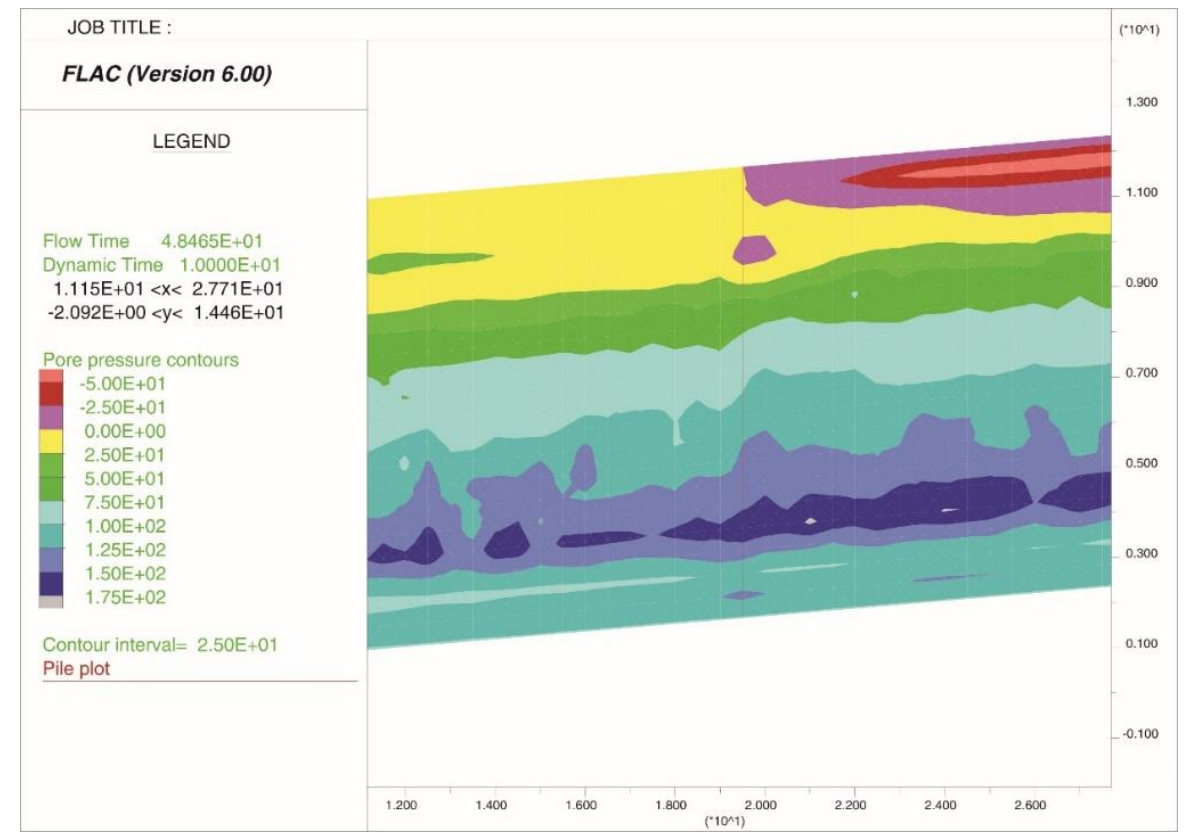

Figure 6. Pore water pressure distribution obtained at the end of the dynamic loading around the pile

Abdoun and Wang (2003) in their centrifuge experiments measured maximum pile bending moments equal to 270 and $305 \mathrm{kNm}$ at the upper and at the lower boundaries of the liquefiable sand layer, respectively. It was measured that the free field ground surface lateral movement and the pile-head deflections were $70 \mathrm{~cm}$ and $85 \mathrm{~cm}$, respectively.

FLAC 2D analysis results showed a free field ground surface horizontal displacement of $131 \mathrm{~cm}$ and a pile-head lateral movement of $125 \mathrm{~cm}$ when using a $2 \%$ viscous damping ratio, while a free field ground surface horizontal displacement of $104 \mathrm{~cm}$ and a pile-head lateral movement of $100 \mathrm{~cm}$ when using a $5 \%$ viscous damping ratio. Figure 7 shows the soil horizontal displacement distribution with depth at the end of the simulation. The computed maximum bending moment between the upper and lower boundaries of the liquefiable sand layer was equal to $320 \mathrm{kNm}$ and $260 \mathrm{kNm}$ when the viscous damping ratio was taken as 2\% and 5\%, respectively. Figure 8 shows the estimated pile displacement vs. depth graph reported in Abdoun and Wang (2003).

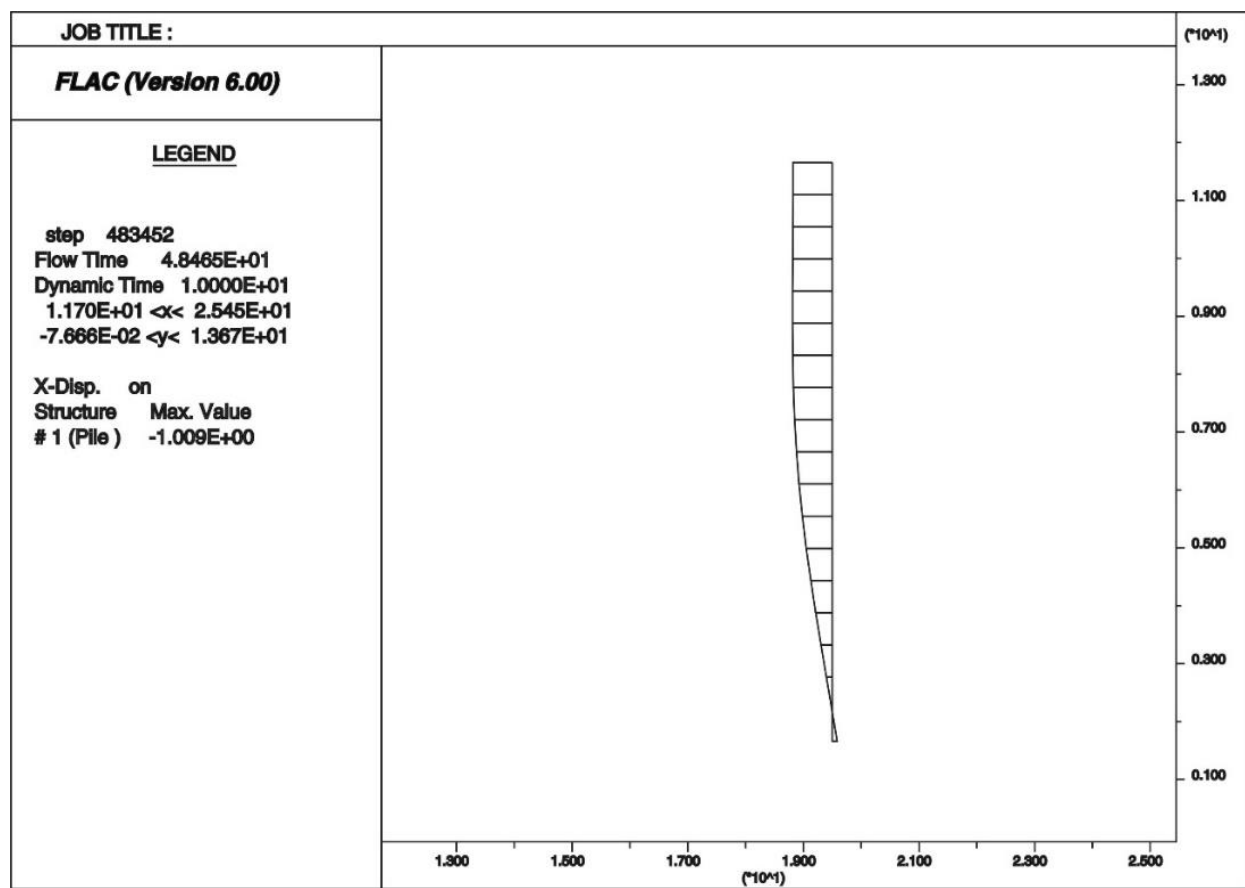

Figure 7. Horizontal displacement distribution at the end of the FLAC simulation 


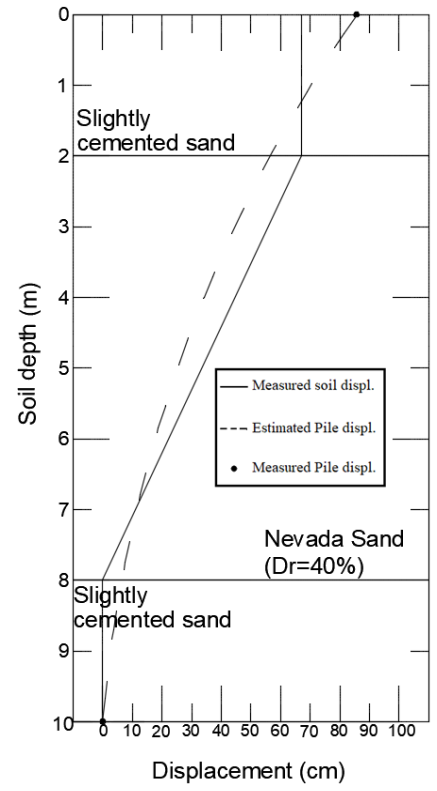

Figure 8. Soil (measured) and Pile (computed) displacement vs. depth reported in modified from Abdoun and Wang (2003)

Pile displacement profile given in figure 8 is the estimation made by Abdoun and Wang (2003) using a beam on the Winkler spring approach. Only soil displacement profile and pile head displacements were measured during the centrifuge test. As can be observed by comparing Figure 7 and Figure 8, the displacement profile obtained with FLAC analysis is consistent in terms of shape with that presented in Abdoun and Wang (2003).

Excess pore-water pressures generated within the liquefiable cohesionless soil, control the shear strength and rigidity. Therefore parameters such as relative density, hydraulic conductivity, the thickness of liquefiable soil, ground slope, presence, and characteristics of non-liquefiable cover soil have very important effects on pile behavior. Increasing soil deformations and loss of soil strength around the pile will result in lower confinement since static vertical loading on the pile is present, even buckling can occur at slender piles. The presence of nonliquefiable soils above liquefiable soil poses an important drag problem. Since they have high rigidity compared to liquefied soil, they can apply very high lateral stresses to piles during lateral flow.

\section{Results}

The comparison between the measured and computed (FLAC 2D) soil displacement profile reveals a quite good agreement. Especially, the shape of the displacement profile at the non-liquefiable upper layer is well captured by FLAC 2D results.

FLAC 2D analysis has been able to correctly reproduce the increase of pore water pressure and the pile bending moment values observed in centrifuge experiments. Nevertheless, the computed displacements are slightly higher than those measured experimentally. This is probably since the Finn-Byrne model could not model increasing rigidity caused by dilation at high shear strains during liquefaction. In the literature, UBCSAND, PM4Sand, and other advanced constitutive models for liquefiable soils can better model the latter issue. Nevertheless, in this work, the Finn-Byrne model was chosen as it was seen to be able to properly reproduce the most relevant features of liquefiable layers and because of its simplicity in defining the input parameters compared to other advanced models.

\section{Conflict of Interest}

No conflict of interest was declared by the authors.

\section{References}

Abdoun, T., and Wang, Y., 2003. Performance of retrofitted pile foundations subjected to seismically induced lateral spreading. Pacific Conference on Earthquake Engineering, University of Canterbury, Christchurch, New Zealand.

Abdoun, T., Dobry, R., Zimmie, T.F., and Zeghal, M., 2005. Centrifuge research of countermeasures to protect pile foundations against liquefaction-induced Lateral Spreading. Journal of Earthquake Engineering, 9(1), 105-125.

Arulmoli, K., Muraleetharan, K.K., Hossain, M.M. and Fruth, L.S., 1992. VELACS: Verification of liquefaction analyses by centrifuge studies, laboratory testing program. Soil Data Report, Irvine, California Report-Project, California, 90-0562. 
Berril, J.B., Christensen, S.A., Keenan, R.P, Okada, W., and Pettinga, J.R., 2001. Studies of LAteral Spreading Forces on a Piled Foundation" Geotechique 51(6), 501-517.

Bhattacharya, S., Tokimatsu, K., Goda, K., Sarkar, R., Shadlou, M., and Rouholamin, M., 2014. Collapse of Showa Bridge during 1964 Niigata earthquake: A quantitative reappraisal on the failure mechanisms. Soil Dynamics and Earthquake Engineering, $65,55-71$.

Boulanger, R.W., Curras. C.J., Kutter, B.L., Wilson, B.W., and Abghari, A., 1998. Seismic soil-pile-structure interaction experiments and analyses. Journal of Geotechnical and Geoenvironmental Engineering, 125(9), 750-759.

Brandenberg, S.J., Boulanger, R.W., Kutter B.L., and Chang, D., 2005. Behavior of pile foundations in laterally spreading ground during centrifuge tests. Journal of Geotechnical and Geoenvironmental Engineering, 131(11), 1378-1391.

Byrne, P.M., 1991. A Cyclic Shear-Volume Coupling and Pore-Pressure Model for Sand. In Proceedings 2nd International Conference on Recent Advances in Geotechnical Earthquake Engineering and Soil Dynamics, Saint. Louis, Missouri, 47-55.

Chang, D., Boulanger, R.W., Kutter, B.L., and Brandenberg, S.J., 2005. Experimental Observations of Inertial and Lateral Spreading Loads on Pile Groups during Earthquakes. Geo-Frontiers Congress, Austin, Texas, United States.

Cubrinovski, M., Ishihara, K.and Furukawazono, K., 1999. Analysis of Full-Scale Tests on Piles in Deposits Subjected to Liquefaction. 2nd International Conference on Earthquake Geotechnical Engineering, Lisbon, Portugal

Cubrinovski, M., Kokusho, , T., and Ishihara, K., 2006. Interpretation from large-scale table tests on piles undergoing lateral spreading in liquefied soils. Soil Dynamics and Earthquake Engineering, 26(2-4), 275-286.

Dobry, R., and Liu, L., 1994. Centrifuge Modelling of Soil Liquefaction. Earthquake Engineering 10. World Conference, Rotterdam, 6801-6809.

Dobry, R., Abdoun, T., O'Rourke, T. D., and Goh, S.H., 2003. Single piles in lateral spreads: Field bending moment evaluation Journal of Geotechnical and Geoenvironmental Engineering, 129(10), 879-889.

Finn, W.D.L., and Fujita, N., 2002. Piles in liquefiable soils: seismic analysis and design issues. Soil Dynamics and Earthquake Engineering, 22(9-12), 731-742.

FLAC2D- Fast Lagrangian Analysis of Continua User Guide, Dynamic Analysis, 2002

FLAC2D, Software program, Version 6, Itasca Consulting.

Haldar, S., and Babu, G.L.S., 2010. Failure mechanisms of pile foundations in liquefiable soil: parametric study. International Journal of Geomechanics, 10(2), 74-84.

Heidary-Torkamani, H., Bargi, K., Amirabadi, R., and McCllough, J.N., 2014. Fragility estimation and sensitivity analysis of an idealized pile-supported wharf with batter piles. Soil Dynamics and Earthquake Engineering, 61-62, 92-106.

Internet: Tyagi, W., 2015. Numerical methods in geotechnical engineering (2)-finite difference method. URL: http://www.webcitation.org/query?url=https\%3A\%2F\%2Fgeosynthetic.wordpress.com $\% 2 \mathrm{~F} 2015 \% 2 \mathrm{~F} 10 \% 2 \mathrm{~F} 16 \% 2 \mathrm{Fnu}$ merical-methods-in-geotechnical-engineering-2-finite-difference-method $\% 2 \mathrm{~F}++\& d a t e=2018-02-21$, Last Access Date: 20.09.2017.

Ishihara, K., and Cubrinovski, M., 1998. Performance of large-diameter piles subjected to lateral spreading of liquefied deposits. 13th Southeast Asian Geotechnical Conference, Taipei.

Liyanapathirana, D.S., and Poulos, H.G., 2002. A numerical model for dynamic soil liquefaction analysis. Soil Dynamics and Earthquake Engineering, 22(9-12), 1007-1015.

Liyanapathirana, D.S., and Poulos, H.G., 2003. A pseudo-static approach for seismic analysis of piles in liquefying soil. Journal of Geotechnical and Geoenvironmental Engineering, 131(12), 1480-1487.

Madabhushi, G., Knappett, J., and Haigh S., 2010. Design of Pile Foundations In Liquefiable Soils " Imperial College Press.

Martin, G.R., and Chen, C.Y., 2005. Response of piles due to lateral slope movement. Computers and Structures, 83(8-9), 588598.

Mazak, E., 2016. Kazık davranışının iki ve üç boyutlu olarak araștırılması, Yüksek Lisans Tezi, Kocaeli Üniversitesi Fen Bilimleri Enstitüsü, Kocaeli.(In Turkish)

Rollins, K.M., Gerber, T.M., Lane, J.D., and Ashford, S.A., 2005. Lateral resistance of a full-scale pile group in liquefied sand. Journal of the Geotechnical and Geoenvironmental Engineering Division, 131(1), 115-125.

Takahashi, A., and Takemura, J., 2005. Liquefaction-induced large displacement of the pile-suppored wharf. Soil Dynamics and Earthquake Engineering, 25(11), 811-825.

Tokimatsu, K., and Asaka, Y., 1998. Effects of liquefaction-induced ground displacements on pile performance in the 1995 Hyogoken-Nambu earthquake. Special Issue of Soil and Foundations, 38, 163-177.

Wilson, D.W., Boulanger, R.W., and Kutter, B.L., 2000. Observed seismic lateral resistance of liquefying sand. Journal of Geotechnical and Geoenvironmental Engineering, 126(10), 898-906.

Yoshida, N., Tazoh, T., Wakamatsu, K., Yasuda, S., Towahata, I., Nakazawa, H., and Kiku, H., 2007.Causes of Showa Bridge collapse in the 1964 Niigata earthquake based on eyewitness testimony. Soils Foundation, 47 (6), pp. 1075-1087. 